\title{
European drug market entries 2015 with new mechanisms of action
}

\author{
Authors: Titus W P van den Heuvel, ${ }^{A}$ Adam F Cohen ${ }^{B}$ and Robert Rissmann ${ }^{C}$
}

In this article, we consider the new drugs approved for the European market in 2015. We present a summary of the new mechanisms of action introduced and highlight three new mechanisms of action with a potentially high future impact: PCSK9 inhibition (alirocumab (Praluent ${ }^{\circledR}$ ) and evolocumab $\left(\right.$ Repatha $\left.{ }^{\circledR}\right)$ ) for hypercholesterolaemia, neprilysin inhibition (sacubitril in combination with valsartan $\left(\right.$ Entresto $\left.^{\circledR}\right)$ ) for heart failure, and interleukin-5 inhibition (mepolizumab (Nucala ${ }^{\circledR}$ )) for asthma.

\section{Introduction}

Each year, a new wave of drugs comes to market, although not all are truly newcomers or particularly innovative. In order to help physicians stay up to date, we provide an overview of the drugs with novel mechanisms of action approved for the European market in 2015. We highlight three innovative new mechanisms with a potentially high impact: proprotein convertase subtilisin/kexin type 9 (PCSK9) inhibition (alirocumab (Praluent ${ }^{\circledR}$, Sanofi-aventis, Bridgewater, NJ, USA) and evolocumab (Repatha ${ }^{\circledR}$, Amgen Inc, Thousand Oaks, CA, USA)) for hypercholesterolaemia, neprilysin inhibition (sacubitril in combination with valsartan (Entresto ${ }^{\circledR}$, Novartis Pharmaceuticals, East Hanover, NJ, USA)) for heart failure, and interleukin-5 inhibition (mepolizumab (Nucala ${ }^{\circledR}$, GlaxoSmithKline, Research Triangle Park, NC, USA)) for asthma. On the basis of European Medicines Agency (EMA) Public Assessment Reports ${ }^{1}$ and literature searches in MEDLINE and Embase, we summarise the clinical application and mechanisms of action of these drugs.

In 2015, the EMA authorised 91 new medicines, introducing 33 novel active substances and 15 new mechanisms of action (Table 1). ${ }^{1}$ Anti-cancer medicines, including cytostatics and immunotherapeutics, represent more than one third of the new active substances. The development of medicines for rare

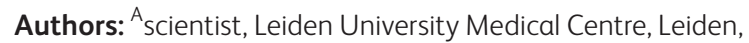
the Netherlands; ${ }^{B}$ professor of clinical pharmacology, Leiden University Medical Centre, Leiden, the Netherlands and CEO, Centre for Human Drug Research, Leiden, the Netherlands; ' associate professor of clinical pharmacology, Leiden University Medical Centre, Leiden, the Netherlands and director of education, Centre for Human Drug Research, Leiden, the Netherlands diseases, with a prevalence of no more than 5 in 10,000 people, has been incentivised through the EMA's orphan designation programme since 2001. Fifteen such medicines were authorised in 2015, including treatment for lysosomal acid lipase deficiency (sebelipase alfa), idiopathic pulmonary fibrosis (nintedanib), and non-24-hour sleep-wake disorder in the totally blind (tasimelteon). The growing trend of introducing medicines for highly specific diseases or disease subtypes is reflected by the large number of biologicals approved. More than half of the approved drugs with a novel mechanism were enzymes, monoclonal antibodies, or other therapeutic proteins.

\section{Alirocumab and evolocumab: PCSK9 inhibition}

For decades, statins have been the mainstay of lipid-lowering therapy for hypercholesterolaemia. However, statins are not sufficiently effective in all patients and tolerability issues, such as myopathy, can preclude their use. As there are few alternative lipid-lowering drug therapies, the recent market approval of the two PCSK9 inhibitors, alirocumab ${ }^{2}$ and evolocumab, ${ }^{3}$ is interesting from a mechanistic viewpoint.

\section{Mechanism}

Alirocumab and evolocumab are recombinant human IgG1 monoclonal antibodies that target PCSK9. ${ }^{2,3}$ PCSK9 binds to low-density lipoprotein (LDL) receptors on hepatocytic cell

\section{Key points}

In 2015, the EMA authorised 91 new medicines with 33 novel active substances and 15 new mechanisms of action.

Trends in new drugs are biologics, drugs for specific subtypes of diseases and orphan diseases.

The pharmacological mechanisms of three newcomers PCSK9-inhibition in hypercholesterolemia, inhibition of IL- 5 by monoclonal antibody in asthma, combination of valsartan with a neprilysin-inhibitor in heart failure - are highlighted.

KEYWORDS: Pharmacology, market approval, first in class, drug mechanisms, hypercholesterolaemia, heart failure, asthma 
Table 1. New mechanisms of 2015

\begin{tabular}{|c|c|c|c|c|c|c|c|}
\hline $\begin{array}{l}\text { Proprietary } \\
\text { name }\end{array}$ & $\begin{array}{l}\text { Active } \\
\text { substance }\end{array}$ & $\begin{array}{l}\text { Marketing } \\
\text { authorisation } \\
\text { holder }\end{array}$ & $\begin{array}{l}\text { Authorisation } \\
\text { date }\end{array}$ & $\begin{array}{l}\text { Orphan } \\
\text { drug? }\end{array}$ & $\begin{array}{l}\text { Mechanism } \\
\text { of action }\end{array}$ & Category & Indication \\
\hline Zykadia & ceritinib & Novartis & 06-05-2015 & no & $\begin{array}{l}\text { ALK } \\
\text { inhibition }\end{array}$ & Cancer & $\begin{array}{l}\text { ALK-positive, locally } \\
\text { advanced or metastatic } \\
\text { non-small cell lung } \\
\text { cancer }\end{array}$ \\
\hline Opdivo & nivolumab & $\begin{array}{l}\text { Bristol-Myers } \\
\text { Squibb }\end{array}$ & $19-06-2015$ & no & $\begin{array}{l}\text { PD-1 } \\
\text { receptor } \\
\text { antagonism }\end{array}$ & Cancer & $\begin{array}{l}\text { Melanoma, non-small cell } \\
\text { lung cancer }\end{array}$ \\
\hline Keytruda & pembrolizumab & $\begin{array}{l}\text { Merck Sharp \& } \\
\text { Dohme }\end{array}$ & $17-07-2015$ & no & $\begin{array}{l}\text { PD-1 } \\
\text { receptor } \\
\text { antagonism }\end{array}$ & Cancer & Advanced melanoma \\
\hline Unituxin & dinutuximab & $\begin{array}{l}\text { United } \\
\text { Therapeutics } \\
\text { Europe }\end{array}$ & $14-08-2015$ & yes & GD2 binding & Cancer & High-risk neuroblastoma \\
\hline Blincyto & blinatumomab & Amgen Europe & $23-11-2015$ & yes & $\begin{array}{l}\text { Bispecific } \\
\text { CD19- } \\
\text { directed } \\
\text { CD3 T-cell } \\
\text { engagement }\end{array}$ & Cancer & $\begin{array}{l}\text { Philadelphia chromosome } \\
\text { negative B-precursor } \\
\text { acute lymphoblastic } \\
\text { leukaemia }\end{array}$ \\
\hline Imlygic & $\begin{array}{l}\text { talimogene } \\
\text { laherparepvec }\end{array}$ & Amgen Europe & $16-12-2015$ & no & $\begin{array}{l}\text { Oncolytic } \\
\text { virus }\end{array}$ & Cancer & Melanoma \\
\hline Repatha & evolocumab & Amgen Europe & $17-07-2015$ & no & $\begin{array}{l}\text { PCSK9 } \\
\text { inhibition }\end{array}$ & Cardiovascular & $\begin{array}{l}\text { Hypercholesterolaemia } \\
\text { and mixed } \\
\text { dyslipidaemia }\end{array}$ \\
\hline Praluent & alirocumab & Sanofi-Aventis & 23-09-2015 & no & $\begin{array}{l}\text { PCSK9 } \\
\text { inhibition }\end{array}$ & Cardiovascular & $\begin{array}{l}\text { Hypercholesterolaemia } \\
\text { and mixed dyslipidaemia }\end{array}$ \\
\hline Entresto & $\begin{array}{l}\text { sacubitril/ } \\
\text { valsartan }\end{array}$ & Novartis & $19-11-2015$ & no & $\begin{array}{l}\text { Neprilysin } \\
\text { inhibition/ } \\
\text { AT1 receptor } \\
\text { antagonism }\end{array}$ & Cardiovascular & $\begin{array}{l}\text { Symptomatic chronic } \\
\text { heart failure with reduced } \\
\text { ejection fraction }\end{array}$ \\
\hline Praxbind & idarucizumab & $\begin{array}{l}\text { Boehringer } \\
\text { Ingelheim } \\
\text { International }\end{array}$ & $20-11-2015$ & no & $\begin{array}{l}\text { Dabigatran } \\
\text { inhibition }\end{array}$ & $\begin{array}{l}\text { Haematology } \\
\text { and } \\
\text { haemostaseology }\end{array}$ & $\begin{array}{l}\text { Rapid reversal of } \\
\text { dabigatran anticoagulant } \\
\text { effects }\end{array}$ \\
\hline Sivextro & tedizolid & $\begin{array}{l}\text { Merck Sharp \& } \\
\text { Dohme }\end{array}$ & 23-03-2015 & no & $\begin{array}{l}\text { Oxazolidinone } \\
\text { antibiotic } \\
\text { (prodrug) }\end{array}$ & Infections & $\begin{array}{l}\text { Acute bacterial skin and } \\
\text { skin structure infections }\end{array}$ \\
\hline Hetlioz & tasimelteon & $\begin{array}{l}\text { Vanda } \\
\text { Pharmaceuticals }\end{array}$ & 03-07-2015 & yes & $\begin{array}{l}\text { Melatonin } \\
\text { receptor } \\
\text { agonism }\end{array}$ & Other & $\begin{array}{l}\text { Non-24-hour sleep-wake } \\
\text { disorder }\end{array}$ \\
\hline Orkambi & $\begin{array}{l}\text { lumacaftor/ } \\
\text { ivacaftor }\end{array}$ & $\begin{array}{l}\text { Vertex } \\
\text { Pharmaceuticals }\end{array}$ & 19-11-2015 & no & $\begin{array}{l}\text { CFTR } \\
\text { potentiation }\end{array}$ & Pneumonology & Cystic fibrosis \\
\hline Nucala & mepolizumab & GlaxoSmithKline & $02-12-2015$ & no & IL-5 inhibition & Pneumonology & $\begin{array}{l}\text { Severe refractory } \\
\text { eosinophilic asthma in } \\
\text { adult patients }\end{array}$ \\
\hline Fexeric & $\begin{array}{l}\text { ferric citrate } \\
\text { coordination } \\
\text { complex }\end{array}$ & $\begin{array}{l}\text { Keryx } \\
\text { Biopharma }\end{array}$ & 23-09-2015 & no & $\begin{array}{l}\text { Dietary } \\
\text { phosphate } \\
\text { precipitation }\end{array}$ & Uro-nephrology & $\begin{array}{l}\text { Hyperphosphataemia } \\
\text { in chronic kidney } \\
\text { disease }\end{array}$ \\
\hline
\end{tabular}

ALK = anaplastic lymphoma kinase; AT1 = angiotensin II receptor, type 1; CFTR = cystic fibrosis transmembrane conductance regulator; PCSK9 = proprotein convertase subtilisin/kexin type 9; PD-1 = programmed cell death protein 1. 


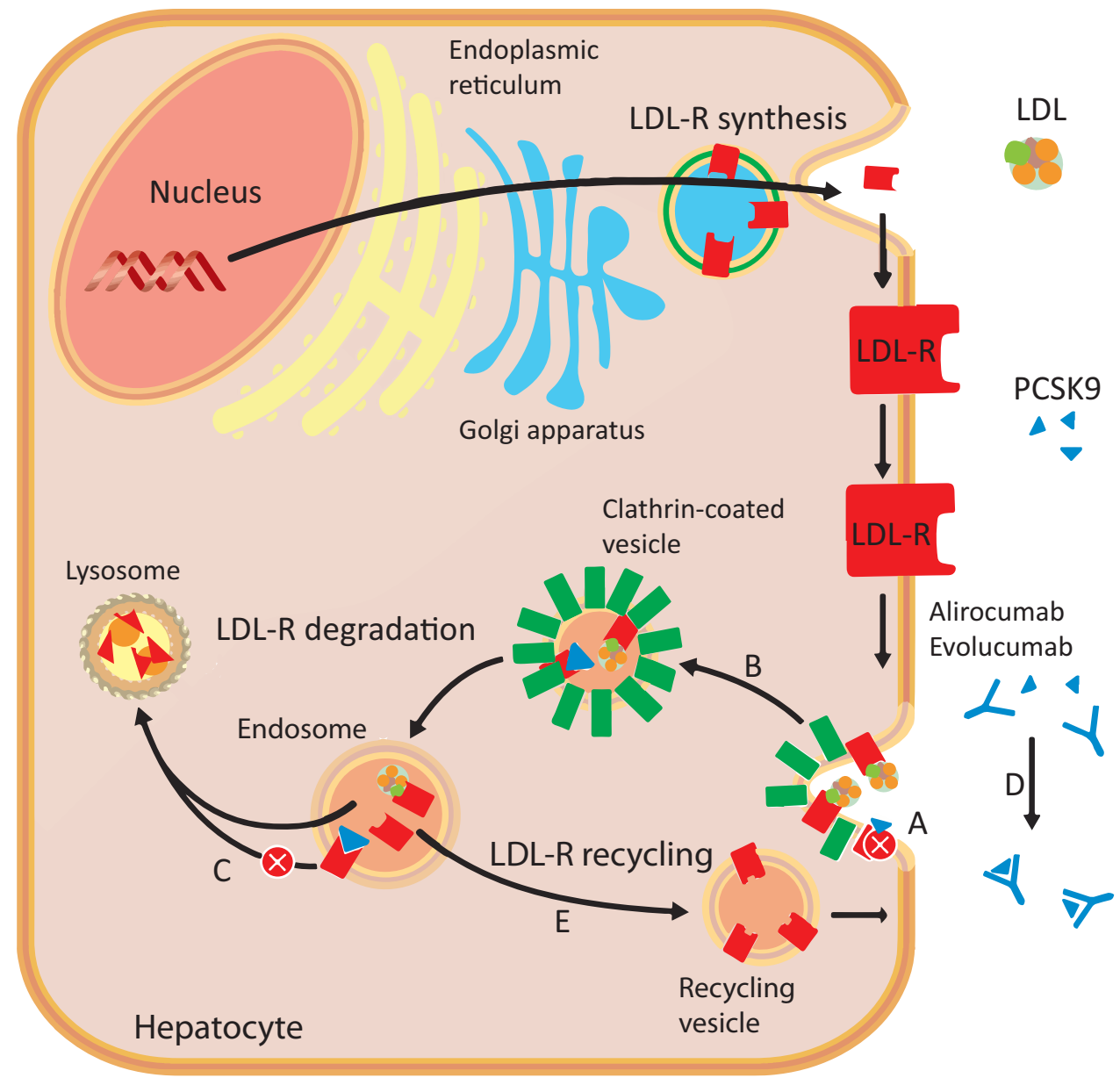

Fig 1. Effect of alirocumab and evolocumab on PCSK9-mediated degradation of LDL-R. A - PCSK9 binds to LDL-R, locking it in an open conformation; $\mathrm{B}$ - the resulting complex is transported from the cell membrane into the cell by clathrin-mediated endocytosis; $C$ - the open conformation of LDL-R causes the complex to be targeted for lysosomal degradation instead of recycling; D - alirocumab and evolocumab bind to PCSK9, precluding it from binding to $L D L-R$ and resulting in increased net $L D L-R$ recycling (E). $L D L-R=$ low-density lipoprotein receptor; PCSK9 = proprotein convertase subtilisin/kexin type 9. Reproduced from the Teaching Resource Centre Pharmacology.

membranes, locking the receptors in an open conformation that targets them for lysosomal degradation instead of recycling (Fig 1). As the number of LDL receptors decreases, lipoprotein internalisation is reduced and plasma LDL levels concomitantly increase. ${ }^{4}$ Alirocumab and evolocumab bind PCSK9, rendering it unable to interact with LDL receptors. As a result, LDL receptors are upregulated and plasma LDL-C levels decrease.

\section{Indication}

Alirocumab and evolocumab are authorised for the treatment of primary hypercholesterolaemia (non-familial and heterozygous familial) or mixed dyslipidaemia in adults as an adjunct to diet either (a) in combination with a statin or statin with other lipidlowering therapies in patients unable to reach LDL-C targets with the maximum tolerated dose of a statin or (b) alone or in combination with other lipid-lowering therapies in patients who do not tolerate statins or for whom a statin is contraindicated. ${ }^{2,3}$

Evolocumab is also authorised for the treatment of homozygous familial hypercholesterolaemia in patients aged 12 years and older in combination with other lipid-lowering therapies. ${ }^{3}$

\section{Clinical application}

Lipiniski et al recently carried out a meta-analysis of 17 clinical trials in which patients were randomised to PCSK9 inhibitors, placebo, ezetimibe, or PCSK9 inhibitors and ezetimibe. ${ }^{5}$ They found that monotherapy with PCSK9 inhibitors led to a 57\% reduction in LDL-C and 36\% reduction in total cholesterol. The largest reductions in serum lipid levels were achieved when PCSK9 inhibitors were combined with ezetimibe: LDL-C was reduced by $69 \%$ and total cholesterol by $46 \%$; statins commonly reduce LDL-C by 30-64\%. Mortality and cardiovascular events were not primary endpoints in any of the studies but are currently under investigation. It remains to be seen whether these compounds will produce further reductions in cardiovascular events compared with statins, as they are more expensive and less convenient to administer.

Alirocumab and evolocumab are administered by subcutaneous injection every 2 weeks (starting dose $75 \mathrm{mg}$ and $140 \mathrm{mg}$, respectively); evolocumab may also be administered once a month at a dose of $420 \mathrm{mg}$. Common adverse effects (1-10\%) include local injection site reactions, nasopharyngitis and upper respiratory tract infections. ${ }^{2,3}$

\section{Sacubitril/valsartan: neprilysin inhibition}

Antihypertensive drug treatment is an important step in the management of heart failure. Beta-blockers, angiotensin converting enzyme (ACE) inhibitors, angiotensin II receptor antagonists and mineralocorticoid receptor antagonists are treatments proven to reduce mortality. Sacubutril/valsartan 
Fig 2. Effect of sacubutril/valsartan on the events of neuro-humoral remodelling events associated with heart failure. ANP and BNP have a vasodilative effect. The endogenous enzyme neprilysin breaks these down, inhibiting vasodilation. Sacubitril prevents neprilysin from degrading ANP and BNP. Valsartan acts on the RAAS system by inhibiting the angiotensin II type 1 receptor. ANP = atrial natriuretic peptide; $B N P=$ brain natriuretic peptide; $\mathrm{EF}=$ ejection fraction. Reproduced from the Teaching Resource Centre Pharmacology.

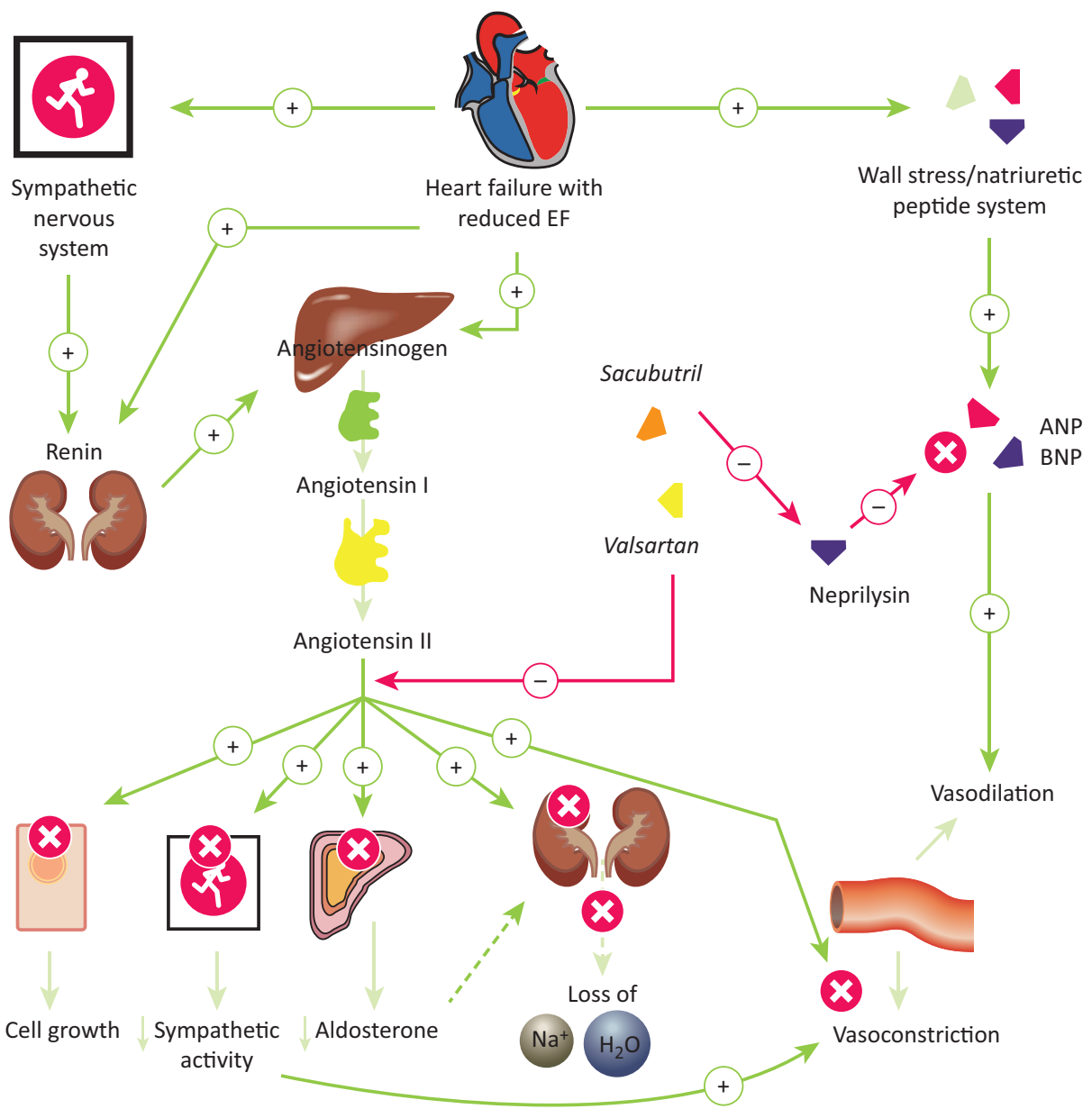

$\left(\text { Entresto }{ }^{\circledR}\right)^{6}$ is an innovative addition to these drug treatment options, acting on the natriuretic peptide system as well as the more familiar renin-aldosterone-angiotensin system.

\section{Mechanism}

Neprilysin, a neutral endopeptidase, breaks down a number of vasoactive peptides with beneficial haemodynamic effects, including atrial natriuretic peptide, bradykinin and adrenomedullin. Inhibition of neprilysin by sacubutril leads to increased levels of these peptides, countering the vasoconstriction, sodium retention and other maladaptive neurohumoral overcompensation responses characteristic of heart failure, as depicted in Fig $2 .^{7}$

\section{Indication}

Sacubutril/valsartan is approved for the treatment of symptomatic chronic heart failure with reduced ejection fraction, ${ }^{6}$ referred to in National Institute for Health and Care Excellence guidelines as heart failure due to left ventricular systolic dysfunction. ${ }^{9}$

\section{Clinical application}

In the PARADIGM-HF (prospective comparison of ARNi with an ACE inhibitor to determine impact on global mortality and morbidity in heart failure) study, patients were randomised to treatment with either sacubitril/valsartan or the ACE inhibitor enalapril. The primary outcome measure was a composite of death from cardiovascular causes and hospitalisation for heart failure. ${ }^{10}$ Significantly fewer patients in the sacubutril/valsartan group experienced the primary outcome (hazard ratio 0.80, $95 \%$ CI $0.73-0.87$ ) or death from any cause (hazard ratio 0.84 , 95\% CI 0.76-0.93). ${ }^{10}$

Treatment with sacubutril/valsartan is normally started with one tablet of $49 \mathrm{mg} / 51 \mathrm{mg}$ twice daily. After 2-4 weeks, the dose is doubled to one tablet of $97 \mathrm{mg} / 103 \mathrm{mg}$ twice daily, if tolerated by the patient. ${ }^{6}$

Contraindications include concomitant treatment with ACE inhibitors (which can cause serious angioedema), aliskirencontaining medicines, hereditary or idiopathic angioedema, liver disease and pregnancy in the second or third trimester. ${ }^{6}$ Like ACE inhibitors, sacubutril/valsartan very commonly $(\geq 10 \%)$ causes hyperkalaemia and hypotension; the former less commonly than with ACE inhibitors, the latter more so. Other adverse effects include renal impairment $(\geq 10 \%)$ and, commonly (1-10\%), renal failure, hypokalaemia, hypoglycaemia, dizziness, cough, gastrointestinal disorders and fatigue. , $10^{-10}$

\section{Mepolizumab: IL-5 inhibition}

Despite treatment with systemic corticosteroids or highdose inhaled corticosteroids in combination with additional 


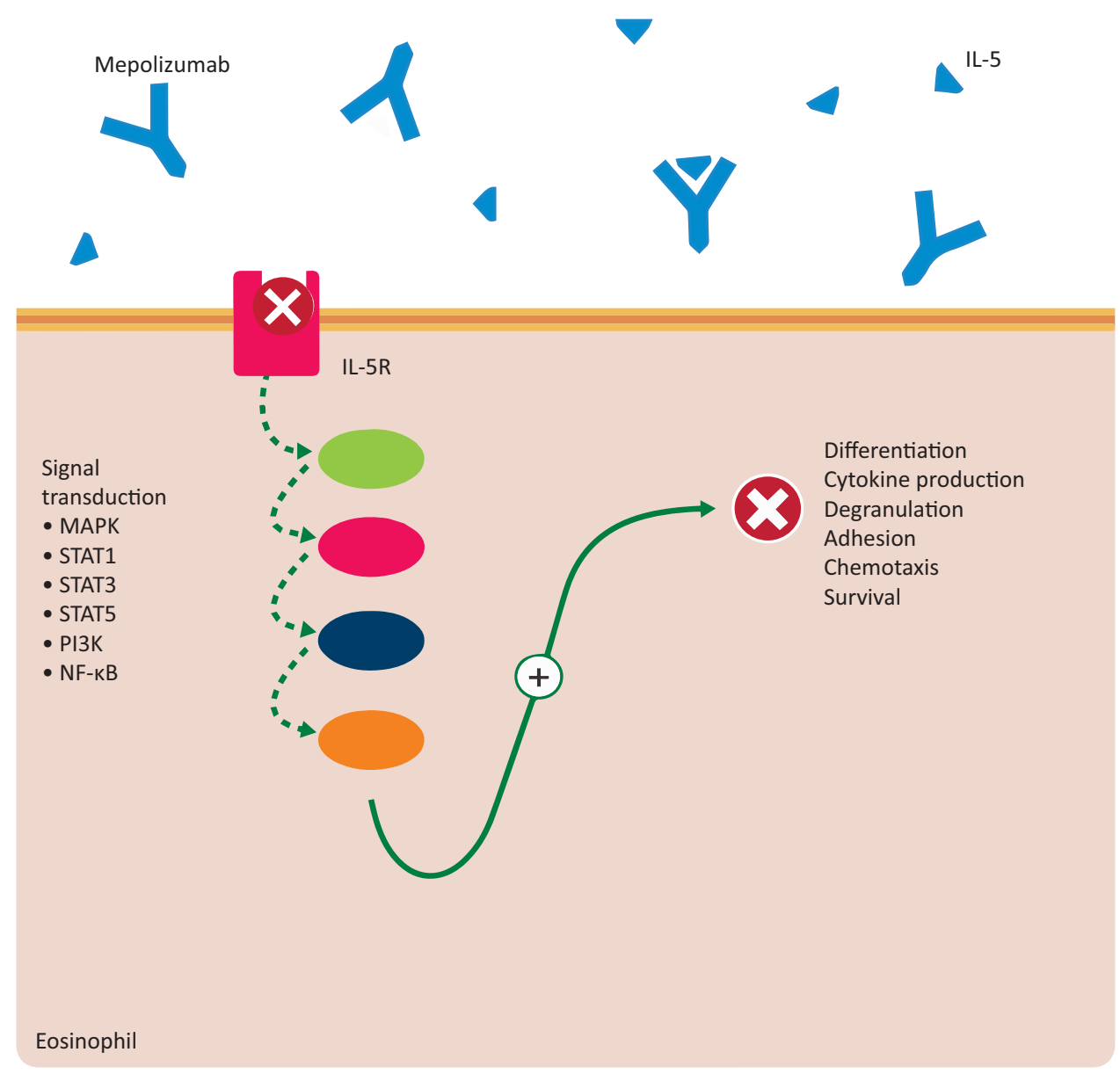

Fig 3. Mepoluzimab and IL-5mediated signal transduction in eosinophils. IL-5 binds to the IL-5-receptor on the plasma membrane, stimulating a number of signal transduction pathways. The MAPK pathway promotes eosinophil differentiation, cytokine production, and degranulation. STAT1, STAT3 and STAT5 pathways stimulate the expression of genes involved in eosinophil survival. Activation of PI3K and NF-KB pathways result in eosinophil adhesion and chemotaxis. IL-5R $=$ interleukin 5 receptor; MAPK $=$ mitogenactivated protein kinases; NF$\kappa \mathrm{B}=$ nuclear factor kappa $\mathrm{B} ;$ PI3K $=$ phosphoinositide 3-kinase; STAT = signal transducer and activator of transcription. Reproduced from the Teaching Resource Centre Pharmacology.

maintenance treatment(s), frequent asthma exacerbations remain a problem in some patients. Mepolizumab may offer relief for patients suffering severe refractory asthma with persistent eosinophilic inflammation.

\section{Mechanism}

Some forms of severe asthma are associated with elevated blood and sputum eosinophil levels. ${ }^{11}$ IL-5 is a key mediator of pulmonary eosinophilia; ${ }^{12,13}$ it supports the proliferation and differentiation of precursor cells into mature eosinophils in bone marrow and stimulates chemotaxis and adhesion of eosinophils in lung tissue (Fig 3). Mepolizumab is a recombinant IgG1 monoclonal antibody that targets IL-5, preventing it from binding to the IL-5 receptor on eosinophil precursors.

\section{Indication}

Mepolizumab is indicated for severe refractory eosinophilic asthma in adults, as an add-on to inhalation or systemic glucocorticoid therapy. ${ }^{14}$

\section{Clinical application}

Mepolizumab is a new treatment for patients with severe eosinophilic refractory asthma. In two clinical trials, patients receiving mepolizumab experienced roughly half as many clinically significant asthma exacerbations per year compared with patients taking placebo. ${ }^{15,16}$ In another study, mepolizumab use was associated with a significant reduction in oral glucocorticoid use compared with placebo (odds ratio $2.39,95 \%$ CI $1.25-4.56) .{ }^{17}$

Mepolizumab is administered by subcutaneous injection of $100 \mathrm{mg}$ every 4 weeks.

Headache is a very common $(>10 \%)$ adverse effect of mepolizumab. Common (1-10\%) adverse reactions include urinary and lower respiratory tract infections, abdominal pain, eczema, back pain and local injection site reactions.

\section{Conclusion}

We have briefly discussed the trends in European drug approvals in 2015. Three innovative, new mechanisms were presented in detail, namely PCSK9 inhibition in hypercholesterolaemia, inhibition of IL- 5 by monoclonal antibodies in asthma and the combination of valsartan with a neprilysin inhibitor in heart failure. We estimate that these compounds may prove important in general clinical practice, although additional large studies will have to precede such a development. 


\section{Conflicts of interest}

The authors have no conflicts of interest to declare.

\section{Acknowledgements}

Publication of new mechanism series is not to be confused with endorsement of use in clinical practice.

Copyright of the images belongs to Leiden University, but use of the images (which are also available at http://coo.lumc.nl/trc) is free.

\section{References}

1 European Medicines Agency. European public assessment reports. London: European Medicines Agency. Available online at www. ema.europa.eu/ema/index.jsp?curl=pages/medicines/landing/ epar_search.jsp [Accessed 30 June 2016].

2 European Medicines Agency. Praluent: EPAR - product information. European public assessment report. London: European Medicines Agency, 2015. Available online at http://www.ema.europa.eu/ docs/en_GB/document_library/EPAR__Product_Information/ human/003882/WC500194521.pdf [Accessed 30 June 2016].

3 European Medicines Agency. Repatha: EPAR - product information. European public assessment report. London: European Medicines Agency, 2015. Available online at http://www.ema.europa.eu/ docs/en_GB/document_library/EPAR___Product_Information/ human/003766/WC500191398.pdf [Accessed 30 June 2016].

4 Lambert G, Sjouke B, Choque B, Kastelein JJ, Hovingh GK. The PCSK9 decade. J Lipid Res 2012;53:2515-24.

5 Lipinski MJ, Benedetto U, Escarcega RO et al. The impact of proprotein convertase subtilisin-kexin type 9 serine protease inhibitors on lipid levels and outcomes in patients with primary hypercholesterolaemia: a network meta-analysis. Eur Heart J 2016;37:536-45.

6 European Medicines Agency. Entresto: EPAR - product information. European public assessment report. London: European Medicines Agency, 2015. Available online at www.ema.europa.eu/docs/en_GB/ document_library/EPAR_-_Product_Information/human/004062/ WC500197536.pdf [Accessed 30 June 2016].
7 Braunwald E. The path to an angiotensin receptor antagonistneprilysin inhibitor in the treatment of heart failure. J Am Coll Cardiol 2015;65:1029-41.

8 Packer M, Califf RM, Konstam MA et al. Comparison of omapatrilat and enalapril in patients with chronic heart failure: the Omapatrilat Versus Enalapril Randomized Trial of Utility in Reducing Events (OVERTURE). Circulation 2002;106:920-6.

9 National Institute for Health and Care Excellence. Chronic heart failure in adults: management. NICE clinical guideline No 108. London: NICE, 2010.

10 McMurray JJ, Packer M, Desai AS et al. Angiotensin-neprilysin inhibition versus enalapril in heart failure. N Engl J Med 2014;371:993-1004.

11 Bel EH, Sousa A, Fleming L et al. Diagnosis and definition of severe refractory asthma: an international consensus statement from the Innovative Medicine Initiative (IMI). Thorax 2011;66:910-7.

12 Fulkerson PC and Rothenberg ME. Targeting eosinophils in allergy, inflammation and beyond. Nat Rev Drug Discov 2013;12:117-29.

13 Lambrecht BN, Hammad H. The immunology of asthma. Nat Immunol 2015;16:45-56.

14 Agency European Medicines. Nucala: EPAR - product information. European public assessment report. London: European Medicines Agency, 2015. Available online at www.ema.europa.eu/docs/en_GB/ document_library/EPAR_-_Product_Information/human/003860/ WC500198037.pdf [Accessed 30 June 2016].

15 Ortega HG, Liu MC, Pavord ID et al. Mepolizumab treatment in patients with severe eosinophilic asthma. $N$ Engl J Med 2014;371:1198-207.

16 Pavord ID, Korn S, Howarth P et al. Mepolizumab for severe eosinophilic asthma (DREAM): a multicentre, double-blind, placebo-controlled trial. Lancet 2012;380:651-9.

17 Bel EH, Wenzel SE, Thompson PJ et al. Oral glucocorticoid-sparing effect of mepolizumab in eosinophilic asthma. $N$ Engl J Med 2014;371:1189-97.

\section{Address for correspondence: R Rissmann, Centre for Human} Drug Research. Zernikedreef 8, 2333CL Leiden, The Netherlands. Email: rrissmann@chdr.nl 